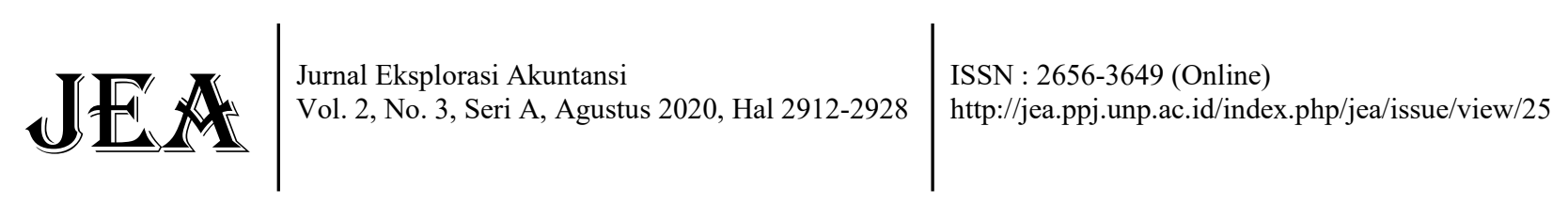

\title{
PENGARUH UMUR PERUSAHAAN, UKURAN PERUSAHAAN, REPUTASI AUDITOR, DAN PERGANTIAN AUDITOR
}

\author{
Ranti Dewi Fortuna ${ }^{1}$, Efrizal Syofyan ${ }^{2}$ \\ 1)Alumni Jurusan Akuntansi Fakultas Ekonomi Universitas Negeri Padang \\ 2)Jurusan Akuntansi Fakultas Ekonomi Universitas Negeri Padang \\ *Korespondensi: rantidewifortuna95@gmail.com
}

\begin{abstract}
The purpose of this study is to analyze the influence of company age, company size, auditor reputation and auditor change on auditor switching. The data used in this study are annual and financial reports on manufacturing companies listed on the Indonesia Stock Exchange (IDX) in the 2014-2018 period. The method of sampling data using purposive sampling method based on certain criteria. Based on the sampling method, a sample of 230 companies was obtained. Testing the hypothesis in this study using multiple linear regression analysis. The results showed that company size, auditor reputation and auditor switching had no effect on audit report lag and company age had a positive effect on audit report lag.
\end{abstract}

Keywords: company age, company size, auditor reputation and auditor switching

How to cite (APA $6^{\text {th }}$ style):

Fortuna, D. R., \& Syofyan, E. (2020). Pengaruh Umur Perusahaan, Ukuran Perusahaan, Reputasi Auditor, dan Pergantian Auditor Terhadap Audit Report Lag. Jurnal Eksplorasi Akuntansi, 2(3), Seri A, 2912-2928.

\section{PENDAHULUAN}

Laporan Keuangan merupakan suatu pertanggung jawaban manajemen kepada pihak eksternal perusahaan yang berupa penyajian kinerja keuangan dalam satu periode. Penyajian laporan keuangan yang tepat waktu sangat diperlukan karena pihak eksternal menggunakan laporan keuangan sebagai pertimbangan dalam pengambilan keputusan. Laporan keuangan yang terlambat disampaikan akan kehilangan sisi informasinya, karena tidak tersedia pada saat pengguna dalam mengambil keputusan. Tujuan dari laporan keuangan adalah pengarah dalam menentukan pedoman atau standar pelaporan keuangan. Investor dan kreditor merupakan pihak yang dianggap dominan dan dijadikan sasaran pelaporan keuangan (Suwardjono, 2002).

Pemegang saham berhak mendapatkan informasi kondisi keuangan dari hasil operasi perusahaannya. Informasi ini digunakan oleh pemegang saham untuk mengevaluasi kinerja manajemen dan untuk membuat keputusan apakah perusahaan tersebut memberikan manfaat atau tidak kepada mereka. Oleh karena itu, laporan keuangan adalah bentuk pertanggungjawaban manajemen untuk pengelolaan entitas sumber daya yang dipercayakan kepadanya. Selain itu, laporan keuangan berfungsi sebagai sarana komunikasi dari manajemen kepada pemegang saham 
mengenai pengambilan keputusan terkait investasi. Laporan keuangan perusahaan juga berfungsi sebagai sarana manajemen dan pemegang saham untuk melihat kelangsungan hidup perusahaan dimasa yang akan datang (Abdillah et al. 2019).

Berdasarkan dari pernyataan PSAK No.1 tentang Penyajian Laporan Keuangan paragraf 43, jika terdapat penundaan yang tidak semestinya dalam pelaporan, maka informasi yang dihasilkan akan kehilangan relevansinya (Dewangga,2015). Relevan artinya bahwa informasi tersebut dapat membantu para pengguna laporan keuangan dalam membuat keputusan ekonomi. Pembuatan keputusan ekonomi dilakukan dengan mengevaluasi peristiwa yang akan terjadi di masa lalu, saat sekarang maupun masa yang akan datang. Salah satu indikator dari relevansi itu adalah ketepatwaktuan (timeliness). Informasi laporan keuangan dikatakan tidak relevan apabila terjadi penundaan publikasi laporan keuangan yang tidak semestinya (Abdillah et al.2019)

Otoritas Jasa Keuangan (OJK) mengatur kewajiban penyampaian laporan keuangan dalam keputusan peraturan Otoritas Jasa Keuangan Nomor: 29/POJK.04/2016 yang menyatakan bahwa Emiten atau Perusahaan Publik wajib menyampaikan Laporan Tahunan kepada Otoritas Jasa Keuangan paling lambat pada akhir bulan keempat setelah tahun buku berakhir. Apabila perusahaan tersebut terlambat menyampaikan laporan keuangan maka dikenakan sanksi administratif sesuai dengan ketentuan yang telah ditetapkan. Sanksi dan denda yang dikenakan pada perusahaan yang terlambat menyampaikan laporan keuangan cukup berat, akan tetapi masih ada perusahaan yang tidak tepat waktu dalam menyampaikan laporan keuangannya.

Audit Report Lag merupakan rentang waktu antara tahun tutup buku atau tahun fiskal dengan tanggal yang tertera pada laporan audit. Rentang waktu tersebut menunjukkan lamanya auditor dalam menyelesaikan pekerjaan auditnya (Danang, 2017). Semakin panjang audit report lag, maka akan berdampak pada lamanya penerbitan laporan keuangan auditan oleh auditor. Sebaliknya jika semakin pendek rentang waktu antara tahun tutup buku dengan tanggal laporan audit, maka semakin cepat publikasi laporan keuangan auditan diterbitkan dan akan terhindar dari sanksi yang diberikan oleh Otoritas Jasa Keuangan. Bursa Efek Indonesia (BEI) mencatat bahwa terdapat 17 perusahaan yang belum menyampaikan laporan keuangan audit per 31 Desember 2016 dan belum melakukan pembayaran denda atas keterlambatan penyampaian laporan keuangan.

Banyak faktor yang memiliki pengaruh terhadap audit report lag telah diteliti oleh peneliti terdahulu diantaranya adalah umur perusahaan, ukuran perusahaan, reputasi auditor dan pergantian auditor. Faktor yang pertama adalah Umur perusahaan adalah kemampuan perusahaan dalam mengendalikan operasinya mulai dari sejak berdiri perusahaan hingga saat ini. Fodio, dkk. (2015) menyatakan semakin lama umur perusahaan itu, maka semakin baik kemungkinannya memiliki prosedur pengendalian internal yang kuat. Dalam tulisan mereka, pernyataan ini didukung oleh Hope dan Langli (2008) yang menyatakan, perusahaan yang lebih muda memiliki pengalaman yang lebih sedikit dengan pengendalian akuntansi dan diduga memiliki kelemahan pengendalian lebih banyak yang dapat menimbulkan penundaan pelaporan.

Faktor kedua yaitu ukuran perusahaan, yang menujukkan besar atau kecilnya sebuah perusahaan. Variabel ukuran perusahaan pada penelitian ini diukur dengan logaritma natural (LN) dari total aset per tahun perusahaan (Banimahd, et al., 2012). Hal ini dikarenakan besarnya total aktiva masing-masing perusahaan berbeda bahkan mempunyai selisih yang besar, sehingga dapat menyebabkan nilai yang ekstrim. Untuk menghindari adanya data yang tidak normal tersebut maka dari total asset perlu di Ln kan.

Faktor ketiga yaitu reputasi auditor, Iskandar dan Estralita (2010) dalam Widhiasari dan Budiartha (2016) menyatakan bahwa auditor dengan reputasi yang baik adalah auditor yang 
terdapat di Kantor Akuntan Publik (KAP) Big Four dengan memiliki kualitas audit yang efektif dan efisien sehingga penyelesaian audit bisa tepat waktu. Selain itu, KAP Big Four diperkirakan memiliki ketersediaan teknologi yang lebih maju dan staf spesialis sehingga, akan lebih efisien dalam melakukan pelayanan mereka. Faktor keempat, pergantian auditor adalah putusnya hubungan perusahaan dengan auditor yang lama dan menggantikannya dengan auditor yang baru (Tambunan, 2014). Untuk bisa menggantikan auditor lama ke auditor baru, Auditor yang baru membutuhkan waktu yang lebih lama untuk mengaudit laporan keuangan karena auditor baru perlu mengenal dari awal karakteristik usaha klien dan sistem yang ada didalamnya.

Alasan penelitian ini dilakukan adalah untuk menguji kembali penelitian-penelitian sebelumnya yang menunjukkan hasil yang tidak konsisten dikarenakan pada penelitianpenelitian sebelumnya menggunakan teori dan pengukuran variabel yang juga berbeda, dimana penelitian sebelumnya menggunakan teori agensi dan teori sinyal sedangkan penelitian ini menggunakan teori kepatuhan, selain itu perbedaan juga terdapat pada periode penelitian yaitu periode sebelumnya hanya 3 tahun yaitu dari tahun 2012-2014, sedangkan penelitian ini 5 tahun yaitu tahun 2014-2018.

Berdasarkan laporan masih banyaknya perusahaan yang terlambat dalam menyampaikan laporan keuangan setiap tahunnya di BEI. Meskipun fakta yang ada pihak berwenang telah menerapkan aturan yang jelas tentang penyampaian laporan keuangan dan disertai sanksi tegas apabila ada pihak yang melanggar. Perusahaan yang tidak tepat waktu dalam pelaporan keuangan maka akan menimbulkan ketidakpercayaan dimata para pengguna laporan keuangan, dan akhirnya akan berakibat pada keberlangsungan perusahaan itu sendiri. Oleh karena itu penelitian ini bertujuan untuk meneliti apakah masih terdapat perusahaan dalam menyampaikan laporan keuangannya, dan untuk meneliti apakah umur perusahaan, ukuran perusahaan, reputasi auditor, dan pergantian auditor dapat mempengaruhi audit report lag pada perusahaan manufaktur yang terdaftar di Bursa Efek Indonesia (BEI).

Pemilihan perusahaan manufaktur dalam penelitian ini dikarenakan banyak diantara perusahaan yang tidak tepat waktu dalam menyampaikan laporan keuangan auditan berasal dari perusahaan manufaktur. Dan perusahaan manufaktur memiliki jumlah perusahaan yang banyak dibandingkan dengan sektor lainnya, sehingga sampel yang diteliti lebih beragam untuk memperkuat dan membuktikan pengaruh antar variabel dalam penelitian ini. Selain itu, perusahaan manufaktur mempunyai kriteria pengungkapan lebih sederhana dibandingkan dengan perusahaan lainnya, sehingga diharapkan dapat mempermudah penelitian ini.

\section{REVIU LITERATUR DAN HIPOTESIS \\ Teori kepatuhan (compliance theory)}

Teori kepatuhan (compliance theory) adalah sebuah pendekatan terhadap struktur organisasi yang mengintegritaskan ide-ide dari model klasik dan partisipan manajemen, Lunenburg (2012) Sedangkan menurut H.C Kelman dalam Anggraeni dan Kiswaran (2011) teori kepatuhan diartikan sebagai suatu kepatuhan yang didasarkan pada harapan akan suatu imbalan usaha untuk menghindari diri dari hukuman yang mungkin dijatuhkan. Berdasarkan pengertian tersebut kepatuhan dapat diartikan sebagai suatu tuntutan untuk melaksanakan sesuatu sesuai target yang telah ditetapkan dan pada akhirnya mengharapkan imbalan atas pencapaian yang dilakukan.

Hubungan teori kepatuhan dengan Audit Report Lag sebagai variabel dependen dalam penelitian ini adalah teori kepatuhan dapat mendorong seseorang untuk lebih mematuhi peraturan yang berlaku, sama halnya dengan perusahaan yang berusaha untuk mencegah keterlambatan pelaporan keuangan karena selain merupakan suatu kewajiban perusahaan untuk 
menyampaikan laporan keuangan tepat waktu, juga akan sangat bermanfaat bagi para pengguna laporan keuangan (Sulistyo, 2010).

\section{Audit Report Lag}

Audit report lag adalah rentang waktu yang dibutuhkan untuk menyelesaikan pekerjaan audit hingga tanggal diterbitkannya laporan audit. diukur berdasarkan lamanya hari yang dibutuhkan untuk memperoleh laporan auditor independen atas audit laporan keuangan tahunan perusahaan, sejak tanggal tutup buku perusahaan yaitu per 31 Desember sampai tanggal yang tertera pada laporan auditor independen (Juanita dan Satwiko, 2012).

\section{Umur Perusahaan}

Umur perusahaan merupakan lamanya perusahaan tersebut telah beroperasi. Umur perusahaan dihitung dari tanggal perusahaan itu berdiri sampai dengan saat perusahaan melakukan tutup buku. Menurut Indra dan Arisudhana (2012), semakin lama umur suatu perusahaan, maka semakin pendek audit report lag perusahaan tersebut. Pernyataan ini dikarenakan perusahaan yang telah lama berdiri dinilai lebih mampu dan telah berpengalaman dalam mengumpulkan, memproses, dan menghasilkan informasi yang dibutuhkan dalam proses audit. Pada umumnya, perusahaan yang sudah lama berdiri telah memiliki banyak cabang atau usaha baru, tidak hanya di beberapa daerah namun juga sampai ke luar negeri. Banyaknya pemeriksaan yang harus dilakukan oleh auditor serta berbagai transaksi dengan tingkat kompleksitas yang tinggi sehingga dapat memperpanjang proses audit ditunjukkan dengan besarnya skala operasi tersebut (Lianto dan Budi 2010).

\section{Ukuran Perusahaan}

Ukuran perusahaan merupakan fungsi dari kecepatan publikasi laporan keuangan karena perusahaan yang besar terdapat internal control yang baik sehingga mendorong auditornya untuk menyelesaikan proses audit secara tepat waktu, Ukuran perusahaan juga akan menjadi pertimbangan bagi para investor karena banyak perusahaan yang telah memiliki ukuran perusahaan yang sangat besar dalam arti telah berkembang dan memiliki banyak cabang di berbagai daerah, sehingga dalam menyajikan laporan keuangannya perusahaan sudah memiliki pengalaman dan paham dalam menyajikan laporan keuangan tersebut dengan tepat waktu (Azizah dan Ratih, 2011).

\section{Reputasi Auditor}

Reputasi auditor (KAP) adalah kepercayaan publik yang dipegang oleh auditor (KAP) atas nama yang besar yang dimilikinya. Reputasi auditor dibagi mejadi dua kelompok besar, yaitu Big Four dan Non Big Four KAP (Abdullah, Mardijuwono dan Habiburrochman, 2019). Berikut ini Kantor Akuntan Publik yang bekerjasama dengan Big Four di Indonesia yaitu: KAP Price Waterhouse Coopers (PWC), bekerjasama dengan KAP Tanudiredja, Wibisana, Rintis \& Rekan/PT Prima Wahana Caraka. KAP Klynveld Peat Marwick Goerdeler (KPMG), bekerjasama dengan KAP Siddharta Widjaja \& Rekan. KAP Ernst \& Young (E \& Y), bekerjasama dengan KAP Purwantono, Suherman, dan Surja (PSS). KAP Deloitte Touche Thomatsu (Deloitte), bekerjasama dengan KAP Osman Bing Satrio \& Eny. KAP dengan reputasi baik yakni KAP Big Four biasanya lebih tepat waktu dalam pelaporan keuangan dibandingkan dengan KAP non Big Four (Bangun dkk., 2012). 


\section{Pergantian Auditor (Auditor Switching)}

Pergantian Auditor merupakan keputusan yang dilakukan oleh perusahaan untuk berpindah auditor, baik yang disebabkan oleh aturan yang ada maupun dengan secara sukarela.hal itu muncul karena adanya kewajiban rotasi audit. Pergantian auditor juga bersifat mandatory (wajib) atau voluntary (sukarela). Pergantian auditor mandatory terjadi disebabkan adanya kewajiban dari ketentuan atau peraturan yang berlaku.Sedangkan pergantian auditor voluntary terjadi karena suatu alasan atau terdapat faktor tertentu dari pihak perusahaan maupun KAP diluar ketentuan atau peraturan yang berlaku (Pawitri \& Yadnyana, 2015).

\section{Hubungan Antara Umur Perusahaan dengan Audit Report Lag.}

Umur perusahaan adalah kemampuan perusahaan menjalankan operasinya sejak berdiri hingga saat ini. Hasil penelitian Lianto dan Budi (2010) mengatakan bahwa pada umumnya, perusahaan yang sudah lama berdiri telah memiliki banyak cabang atau unit usaha baru, tidak hanya di beberapa daerah namun juga sampai ke luar negeri. Banyaknya pemeriksaan yang harus dikaji oleh auditor serta berbagai transaksi dengan tingkat kompleksitas yang tinggi sehingga dapat memperpanjang proses audit ditunjukkan dengan besarnya skala operasi tersebut. Berdasarkan penjelasan tersebut dapat ditarik hipotesis yaitu :

$\mathbf{H}_{1}$ : Umur Perusahaan berpengaruh positif terhadap Audit Report Lag.

\section{Hubungan Antara Ukuran Perusahaan dengan Auditor Report Lag.}

Ukuran perusahaan menunjukkan besar kecilnya sebuah perusahaan. Indikator dilihat dari beberapa sudut pandang seperti total nilai aset, total penjualan, jumlah tenaga kerja, anak perusahaan, dan sebagainya. Besar kecilnya ukuran perusahaan juga dipengaruhi oleh kompleksitas operasional variabel dan intensitastransaksi penjualan. Pada umumnya perusahaan besar dimonitor oleh investor, pengawas permodalan, dan pemerintah. Perusahaan besar juga telah memiliki sistem pengendalian intern yang memadai sehingga memudahkan proses audit (Swami dan Latrini, 2013). Berdasarkan penjelasan tersebut dapat ditarik hipotesis yaitu :

$\mathbf{H}_{2}$ : Ukuran Perusahaan Berpengaruh negatif terhadap Auditor Report Lag.

\section{Hubungan Antara Reputasi Auditor dengan Audit Report Lag.}

Peniliaian reputasi auditor selama ini didasarkan pada hubungan afiliasi KAP di Indonesia dengan KAP yang masuk kategori Big Four. KAP Big Four adalah kelompok empat firma jasa profesional dan akuntansi internasional terbesar, yang menangani mayoritas pekerjaan audit untuk perusahaan publik maupun perusahaan tertutup. Perusahaan degan menggunakan jasa KAP yang bermitra dengan KAP big four cenderung lebih dipercaya bila dibandingkan dengan perusahaan yang menggunakan jasa KAP yang tidak bermitra dengan KAP big four.

Terdapat penelitian yang menyangkut tentang reputasi auditor terhadap audit report lag. Iskandar dan Estralita (2010) menemukan bahwa auditor dengan reputasi yang baik yaitu auditor yang terdapat di Kantor Akuntan Publik (KAP) Big four memiliki kualitas audit yang efektif dan efisien sehingga penyelesaian audit bisa tepat waktu. Berdasarkan penjelasan tersebut dapat ditarik hipotesis yaitu :

$\mathbf{H}_{3}$ : Reputasi Auditor Berpengaruh negatif terhadap Auditor Report Lag

\section{Hubungan Antara Pergantian Auditor (Auditor Switching) dengan Audit Report Lag}

Pergantian auditor merupakan perilaku yang dilakukan oleh perusahaan untuk berpindah auditor yang dimana auditor baru menggantikan auditor lama. Pergantian auditor bisa disebabkan oleh 
kewajiban rotasi yang diatur oleh Pemerintah (mandatory) atau pergantian secara sukarela (voluntary) (Rizqillah, 2013). Sedangkan menurut Prahartari (2013), auditor switching merupakan perilaku yang dilakukan oleh perusahaan untuk berpindah auditor. Dapat disimpulkan bahwa pergantian auditor/auditor switching adalah pergantian auditor/kantor akuntan publik yang dimana audior baru menggantikan auditor lama yang dilakukan oleh perusahaan karena peraturan pemerintah (mandatory) atau pergantian auditor atas keputusan klien secara sukarela (voluntary). Berdasarkan penjelasan tersebut dapat ditarik hipotesis yaitu : $\mathbf{H}_{4}$ : Pergantian Auditor Berpengaruh negatif terhadap Auditor Report Lag.

Kerangka Konseptual

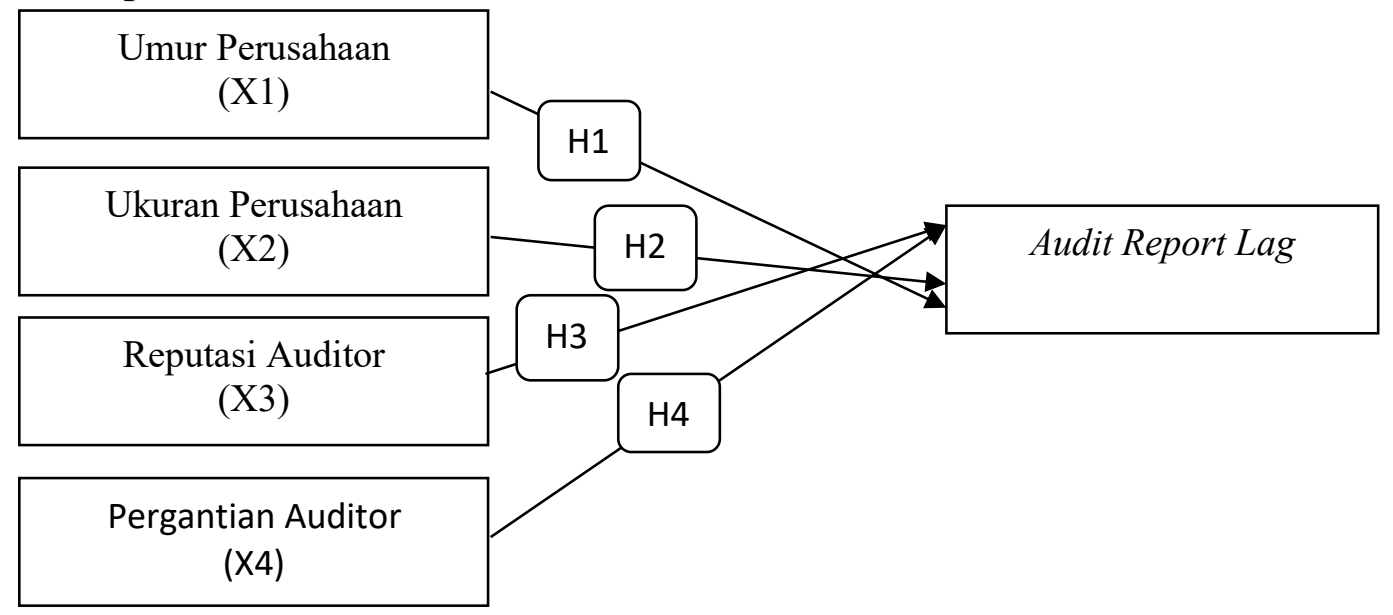

Gambar 1

Kerangka Konseptual

\section{METODE PENELITIAN}

\section{Metode Penelitian}

Jenis penelitian yang dilakukan adalah asosiatif kausal dengan pendekatan kuantitatif. Penelitian asosiatif kausal adalah penelitian yang bertujuan untuk menganalisis hubungan antara satu variabel dengan variabel lainnya atau bagaimana suatu variabel memengaruhi variabel lain. Data yang digunakan bersumber dari laporan keuangan dan tahunan perusahaan yang terdapat di Indonesia Stock Exchange (IDX) (www.idx.co.id).

\section{Populasi dan Sampel}

Populasi merupakan wilayah generalisasi yang terdiri atas sekumpulan objek dengan karakteristik dan kualitas tertentu yang kemudian dipelajari dan ditarik kesimpulannya (Sugiyono, 2012). Populasi sebagai totalitas semua nilai yang mungkin, hasil menghitung ataupun pengukuran, baik kuantitatif maupun kualitatif mengenai karakteristik tertentu dari semua anggota kumpulan yang lebih lengkap dan jelas yang ingin dipelajari sifat-sifatnya. Populasi yang digunakan dalam penelitian ini adalah seluruh perusahaan manufaktur yang terdaftar di Bursa Efek Indonesia dari tahun 2014-2018. Jumlah sampel dalam penelitian ini adalah 230 perusahaan manufaktur untuk lima tahun pengamatan.

Pengambilan sampel dalam penelitian ini dilakukan secara purposive sampling, artinya sampel dipilih berdasarkan pertimbangan subjektif penelitian dimana persyaratan yang dibuat sebagai kriteria harus dipenuhi sebagai sampel. Adapun kriteria sampel yang digunakan adalah: 


\section{Tabel 1}

Kriteria Pengambilan Sampel

\begin{tabular}{|c|l|c|}
\hline No & \multicolumn{1}{|c|}{ Kriteria } & $\begin{array}{c}\text { Jumlah } \\
\text { Perusahaan }\end{array}$ \\
\hline 1 & $\begin{array}{l}\text { Perusahaan manufaktur yang tercatat di Bursa } \\
\text { Efek Indonesia tahun 2014-2018 }\end{array}$ & 167 \\
\hline 2 & $\begin{array}{l}\text { Tidak memiliki data tanggal penyampaian } \\
\text { laporan keuangan ke OJK }\end{array}$ & $(37)$ \\
\hline 3. & $\begin{array}{l}\text { Perusahaan manufaktur yang tidak menyajikan } \\
\text { laporan keuangan menggunakan mata uang } \\
\text { rupiah }\end{array}$ & $(30)$ \\
\hline 4. & Data yang tidak lengkap & $(54)$ \\
\hline \multicolumn{2}{|l|}{ Total Sampel } & 46 \\
\hline \multicolumn{2}{|l|}{ Periode pengamatan sampel 5 tahun (5x 46) } \\
\hline
\end{tabular}

\section{Jenis dan Sumber data}

Data yang digunakan dalam penelitian ini adalah data sekunder. Data sekunder adalah data yang telah dikumpulkan oleh pengumpul data dan dipublikasikan kepada masyarakat pengguna data. Alasan penggunaan data sekunder adalah karena data sekunder mempunyai tingkat validitas data yang dijamin oleh pihak lain, sehingga andal untuk digunakan dalam penelitian (Sekaran, 2013). Sumber data dalam penelitian ini diperoleh dari Bursa Efek Indonesia (BEI) dari tahun 2014 sampai dengan tahun 2018 yang didokumentasikan dalam www.idx.co.id.

\section{Teknik Pengumpulan Data Variabel Dependen}

Pengukuran variable ARL ini diukur dengan menghitung jumlah hari antara tanggal tutup buku perusahaan yaitu 31 Desember hingga tanggal yang tertera pada laporan auditor independen (Mufidah dan Laily, 2019).

\section{Variabel Independen}

\section{a. Umur Perusahaan}

Pengukuran variabel umur perusahaan pada penelitian ini dihitung dari pertama kali perusahaan listing di Bursa Efek Indonesia sampai dengan tahun penelitian. Pengukuran ini digunakan oleh Dibia dan Onwuchekwa (2013) serta Togasima dan Yulius (2014).

\section{b.Ukuran Perusahaan}

Pengukuran variabel ukuran perusahaan pada penelitian ini diukur dengan logaritma natural (Ln) dari total aktiva. Hal ini dikarenakan besarnya total aktiva masing-masing perusahaan berbeda bahkan mempunyai selisih yang besar, sehingga dapat menyebabkan nilai yang ekstrim. Untuk menghindari adanya data yang tidak normal tersebut maka dari total asset perlu di Ln kan. variabel ukuran perusahaan dapat dinyatakan dengan rumus sbb : Ukuran Perusahaan (Size) $=\mathrm{Ln}$ Total Aktiva

\section{c.Reputasi Auditor}

Pengukuran variabel umur perusahaan Reputasi Auditor pada penelitian ini diukur dengan menggunakan variabel dummy, Perusahaan yang menggunakan jasa KAP yang berafiliasi dengan Big Four diberi kode 1 sedangkan perusahaan yang menggunakan jasa KAP non Big Four diberi 
kode 0. Pengukuran ini mengacu pada penelitian Wirakusuma dan Putu (2011), Juanita dan Rutji (2012) dan Puspitasari dan Anggraeni (2012).

\section{d.Pergantian Auditor}

Pengukuran variabel Pergantian auditor (SWITCH) diukur dengan variabel dummy. Perusahaan yang melakukan pergantian auditor selama periode penelitian diberi kode 1 dan perusahaan yang tidak melakukan pergantian auditor diberi kode 0 .

\section{HASIL DAN PEMBAHASAN Hasil Statistik Deskriptif}

Tabel 2

Descriptive Statistics

\begin{tabular}{lrrrrr}
\hline & N & Minimum & Maximum & Mean & $\begin{array}{c}\text { Std. } \\
\text { Deviation }\end{array}$ \\
\hline ARL & 190 & 67,00 & 90,00 & 82,210 & 5,86189 \\
& & & & 5 & \\
AGE & 190 & 3,00 & 36,00 & $\begin{array}{r}20,421 \\
1\end{array}$ & 7,86268 \\
& & & & 18,243 & \\
SIZE & 190 & 5,70 & 31,34 & 6 & 8,62603 \\
BIG4 & 190 &, 00 & 1,00 &, 4368 &, 49731 \\
SWITCH & 190 &, 00 & 1,00 &, 5053 &, 50129 \\
Valid N (listwise) & 190 & & & & \\
\hline
\end{tabular}

Hasil statistika deskriptif menampilkan nilai minimum, nilai maksimum, rata-rata dan standar deviasi dari masing variabel. Audit report lag (ARL) memiliki nilai minimum sebesar 67 hari yang dimiliki oleh perusahaan Arwana Citramulia Tbk (ARNA) pada tahun 2016. Sedangkan nilai maksimum sebesar 90 hari yaitu perusahaan Sepatu Bata Tbk (BATA) pada tahun 2016 dan perusahaan Unilever Indonesia Tbk (UNVR) pada tahun 2018. Dengan rata-rata sebesar 82, 2105 dan standar deviasi 4,86189.

\section{Uji Asumsi Klasik Uji Normalitas}

Uji normalitas dalam model regresi bertujuan untuk menguji bahwa distribusi data sampel yang digunakan telah terdistribusi dengan normal. Metode yang digunakan adalah dengan melihat hasil statistic Kolmogorov-Smirnov atau juga bisa melihat dari nilai Asymp. Sig(2 tailed). Apabila nilai Asymp. Sig(2-tailed) lebih besar dari 0,05 (alpha) maka data berdistribusi normal. Berikut ini merupakan hasil pengujian normalitas pada data: 


\section{Tabel 3}

\section{Data One-Sample Kolmogorov-Smirnov Test}

\begin{tabular}{llr}
\multicolumn{2}{c}{ Data One-Sample Kolmogorov-Smirnov Test } \\
N & Unstandardized Residual \\
& Mean & 190 \\
Normal Parameters ${ }^{\text {a,b }}$ & Std. & $0 \mathrm{E}-7$ \\
& Deviation & \\
& Absolute &, 091 \\
Most Extreme & Positive &, 057 \\
Differences & Negative &,- 091 \\
Kolmogorov-Smirnov Z & 1,252 \\
Asymp. Sig. (2-tailed) &, 087 \\
a. Test distribution is Normal. & \\
b. Calculated from data. & \\
\hline
\end{tabular}

Berdasarkan tabel di atas didapatkan bahwa nilai Asymp. Sig(2-tailed) sebesar 0,087. Nilai tersebut lebih besar dari 0,05 sehingga dapat dikatakan bahwa data sudah berdistribusi normal.

\section{Uji Multikolinieritas}

Asumsi yang paling penting pada analisis regresi berganda adalah variabel bebas saling bebas dengan variabel bebas lainnya. pengujin asumsi multikolinieritas dapat dilihat dari nilai Variance Inflaction Factor (VIF). Jika nilai VIF lebih besar dari 10 maka terjadi multikolinieritas antar variabel bebas. Pengujian multikolinieritas dapat dilihat sebagai berikut:

\section{Tabel 4.}

Pengujian Multikolinieritas Data

\begin{tabular}{|c|c|c|c|c|c|c|c|}
\hline \multirow{3}{*}{ Model } & \multicolumn{4}{|c|}{ Coefficients $^{a}$} & \multirow{3}{*}{ Sig. } & \multirow{2}{*}{\multicolumn{2}{|c|}{$\begin{array}{l}\text { Collinearity } \\
\text { Statistics }\end{array}$}} \\
\hline & \multicolumn{2}{|c|}{$\begin{array}{l}\text { Unstandardized } \\
\text { Coefficients }\end{array}$} & \multirow{2}{*}{$\begin{array}{c}\text { Standardized } \\
\text { Coefficients } \\
\text { Beta }\end{array}$} & \multirow[t]{2}{*}{$\mathrm{T}$} & & & \\
\hline & $\mathrm{B}$ & Std. Error & & & & Tolerance & VIF \\
\hline (Constant) & 80,254 & 1,401 & & 57,286 & ,000 & & \\
\hline $\mathrm{AGE}$ & ,138 & ,046 & ,223 & 2,980 &, 003 & 910 & 1,098 \\
\hline SIZE &,- 028 &, 042 &,- 051 &,- 683 & ,496 & ,934 & 1,071 \\
\hline BIG4 &,- 621 &, 741 &,- 063 &,- 838 & ,403 & ,892 & 1,121 \\
\hline SWITCH &,- 146 & ,701 &,- 015 &,- 209 & ,835 & ,980 & 1,021 \\
\hline
\end{tabular}

Berdasarkan tabel di atas dapat dilihat bahwa nilai VIF dari variabel AGE sebesar 1, 098 variabel SIZE sebesar 1,071 variabel BIG4 sebesar 1,121 dan variabel SWITCH sebesar 1,021. Hal itu berarti bahwa tidak terjadinya multikolinieritas antar variabel bebas karena nilai dari VIF tidak lebih dari 10.

\section{Uji Heteroskedasititas}

Pengujian asumsi heteroskedasititas dapat dilakukan menggunakan uji Levene Statistic dengan kriteria apabilai nilai Sig lebih besar dari 5\% maka dapat dikatakan bahwa asumsi heteroskedasititas terpenuhi. Pengujian heteroskedasititas dapat dilihat sebagai berikut: 


\section{Tabel 5}

Pengujian Heteroskedasititas Data

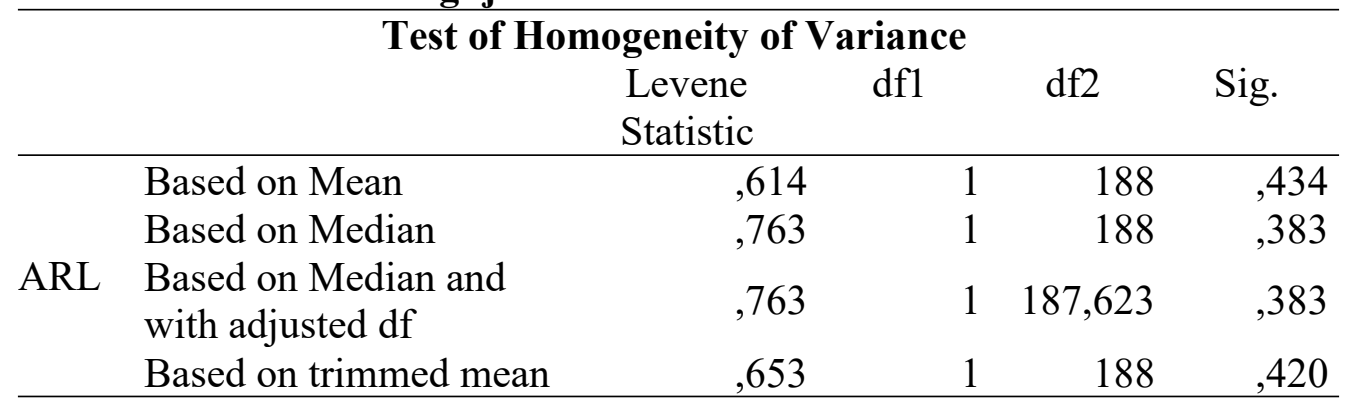

Berdasarkan tabel di atas didapatkan nilai Sig sebesar 0,434. Hal ini berarti bahwa asumsi heteroskedasitas telah terpenuhi karena nilai Sig lebih besar dari 5\%.

\section{Uji Autokorelasi}

Pengujian asumsi heteroskedasititas dapat dilakukan menggunakan uji Levene Statistic dengan kriteria apabilai nilai Sig lebih besar dari 5\% maka dapat dikatakan bahwa asumsi heteroskedasititas terpenuhi. Pengujian heteroskedasititas dapat dilihat sebagai berikut:

\section{Tabel 6}

Pengujian Heteroskedasititas Data

\begin{tabular}{llrrrr}
\hline & & $\begin{array}{c}\text { Test of Homogeneity of Variance } \\
\text { Levene } \\
\text { Statistic }\end{array}$ & df1 & df2 & Sig. \\
\hline \multirow{2}{*}{ ARL } & Based on Mean &, 614 & 1 & 188 &, 434 \\
& Based on Median &, 763 & 1 & 188 &, 383 \\
& Based on Median and &, 763 & 1 & 187,623 &, 383 \\
& with adjusted df &, 653 & 1 & 188 &, 420 \\
\hline
\end{tabular}

Berdasarkan tabel di atas didapatkan nilai Sig sebesar 0,434. Hal ini berarti bahwa asumsi heteroskedasitas telah terpenuhi karena nilai Sig lebih besar dari 5\%.

\section{Uji Hipotesis}

Model regresi linier berganda dapat dilihat berdasarkan Tabel 9, sehingga didapatkan model sebagai berikut:

$$
\mathrm{ARL}=80,254+0,138 \mathrm{AGE}-0,0286 \mathrm{SIZE}-0,621 \mathrm{BIG} 4-0,146 \mathrm{SWITCH}+\varepsilon
$$

Dari model di atas dapat diinterpretasikan kesimpulan bahwa konstanta $\left(\beta_{0}\right)$ memberikan pengurangan sebesar 80,254 pada model. Nilai koefisien $\beta 1$ adalah positif sebesar 0,138 menunjukkan bahwa setiap kenaikan 1 hari variabel umur perusahaan (AGE) akan meningkatkan variabel audit report lag sebesar 0,138 hari dan secara bersaman variabel ukuran perusahaan, reputasi auditor, dan pergantian auditor juga diberikan pada model. Ini memiliki makna, apabila umur perusahaan meningkat maka audi treport lag akan meningkat.

Nilai koefisen $\beta 2$ adalah negatif sebesar 0,028 menunjukkan bahwa bila variabel ukuran perusaan (SIZE) naik sebesar 1 satuan maka akan menurunkan audit report lag sebesar 0,028 
hari dan secara bersaman variabel umur perusahaan, reputasi auditor,dan pergantian auditor juga diberikan terhadap model. Ini memiliki makna, apabila ukuran perusahaan meningkat maka audit report lag akan menurun.

Nilai koefisien $\beta 3$ adalah negatif sebesar 0,621 menunjukkan bahwa apabila perusahaan menggunakan jasa KAP yang berafiliasi dengan Big Four (BIG4) maka akan menurunkan audit report lag sebesar 0,621 haridan secara bersamaan variabel umur perusahaan, ukuran perusahaan dan pergantian auditor diberikan secara bersamaan. Ini memiliki makna, perusahaan menggunakan jasa KAP yang berafiliasi dengan Big Four maka audit report lag akan menurun.

Nilai koefisien $\beta 4$ adalah negatif sebesar 0,146 menunjukkan bahwa setiap terjadi pergantian auditor selama periode penelitian akan menurunkan audit report lag sebesar 0,146 hari dan secara bersamaan variabel umur perusahaan, ukuran perusahaan, dan reputasi auditor juga diberikan pada model. Ini memiliki makna, apabila terjadi pergantian auditor selama periode penelitian maka audit report lag akan menurun.

\section{Koefisien Determinasi $\left(\boldsymbol{R}^{2}\right)$}

Koefisien determinasi merupakan nilai proporsi yang mengukur keragaman atau variasi total sekitar nilai tengah variabel terikat yang dapat diterangkan oleh variabel lain. Berdasarkan Tabel 11 nilai dari $R^{2}$ sebesar 0,053 memiliki makna bahwa 5,3\% audit report lag dapat dijelaskan oleh variabel umur perusahaan, ukuran perusahaan, reputasi auditor, dan pergantian auditor. Sisanya sebesar $94,7 \%$ ditentukan oleh variabel lain yang tidak dimasukkan dalam model.

\section{Pengujian Koefisien Regresi Simultan (Uji F)}

Uji $\mathrm{F}$ digunakan untuk melihat pengaruh variabel bebas terhadap variabel terikat secara bersamaan. Pengujian F dapat dilihat sebagai berikut:

\begin{tabular}{|c|c|c|c|c|c|c|}
\hline \multicolumn{7}{|c|}{$\begin{array}{c}\text { Tabel } 7 \\
\text { ANOVA }^{\mathrm{a}}\end{array}$} \\
\hline Model & & $\begin{array}{l}\text { Sum of } \\
\text { Squares }\end{array}$ & Df & Mean Square & $\mathrm{F}$ & Sig. \\
\hline \multirow{3}{*}{1} & Regression & 236,381 & 4 & 59,095 & 2,584 &, $039^{\mathrm{b}}$ \\
\hline & Residual & 4231,198 & 185 & 22,871 & & \\
\hline & Total & 4467,579 & 189 & & & \\
\hline \multicolumn{7}{|c|}{ a. Dependent Variable: ARL } \\
\hline
\end{tabular}

Berdasarkan tabel di atas dengan menggunakan tingkat signifikansi $0,05(\alpha=5 \%)$ hipotesis diterima yang berarti secara bersama-sama variabel umur perusahaan (AGE), ukuran perusahaan (SIZE), reputasi auditor (BIG4), dan pergantian auditor (SWITCH) berpengaruh terhadap ketepatan waktu penyampaian laporan keuangan karena nilai Sig. lebih kecil dari 0,05 yaitu sebesar 0,039 .

\section{Uji Koefisien Regresi Parsial (Uji T)}

Uji t digunakan untuk melihat pengaruh variabel bebas terhadap variabel terikat. Apabilai nilai Sig lebih kecil dari alpha $(0,05)$ maka variabel tersebut memberikan pengaruh terhadap variabel terikat. Pengujian dapat dilihat pada Tabel 9. Berdasarkan Tabel 9 didapatkan nilai Sig dari AGE 
sebesar 0,003 lebih kecil dari alpha (0,05). Maka dapat dikatakan bahwa variabel AGE memberikan pengaruh terhadap audit report lag secara signifikan.

Nilai Sig, dari variabel SIZE sebesar 0,496 lebih besar dari alpha $(0,05)$. Maka dapat dikatakan bahwa variabel AGE tidak memberikan pengaruh terhadap audit report lag secara signifikan. Nilai Sig, dari variabel BIG4 sebesar 0,403 lebih besar dari alpha (0,05). Maka dapat dikatakan bahwa variabel BIG4 tidak memberikan pengaruh terhadap audit report lag secara signifikan. Nilai Sig, dari variabel SWITCH sebesar 0,835 lebih besar dari alpha $(0,05)$. Maka dapat dikatakan bahwa variabel SWITCH tidak memberikan pengaruh terhadap audit report lag secara signifikan.

\section{Pembahasan}

\section{Pengaruh Umur Perusahaan Terhadap Audit Report Lag}

Hasil uji hipotesis pada variabel Umur Perusahaan memperlihatkan bahwa Umur Perusahaan berpengaruh terhadap Audit Report Lag pada perusahaan manufaktur, Dengan demikian hipotesis pertama (H1) diterima yang menyatakan Umur perusahaan berpengaruh terhadap Audit Report Lag. Hal ini menunjukkan bahwa perusahaan yang telah lama berdiri dinilai lebih mampu dan telah berpengalaman dalam mengumpulkan, memproses, dan menghasilkan informasi yang dibutuhkan dalam proses audit, banyaknya pemeriksaan yang harus dilakukan oleh auditor serta berbagai transaksi dengan tingkat kompleksitas yang tinggi sehingga dapat memperpanjang proses audit ditunjukkan dengan besarnya skala operasi tersebut

Hasil penelitian ini sejalan dengan penelitian yang dilakukan Siti Amariyah, Masyhad, Nurul Qomari (2016) menunjukkan bahwa umur perusahaan berpengaruh terhadap audit report lag. Sejalan juga dengan hasil penelitian Laksono dan Dul (2014) yang membuktikan bahwa umur perusahaan berpengaruh positif signifikan terhadap audit delay. Ini berarti bahwa perusahaan yang lebih tua cenderung memiliki penyelesaian audit yang lebih lama dan sebaliknya demikian. Kemudian penelitian yang dilakukan oleh penelitian Petronila (2007) menunjukkan bahwa umur perusahaan berpengaruh negatif terhadap audit report lag. Semakin lama umur perusahaan suatu perusahaan maka jangka waktu pelaporan auditnya akan semakin cepat demikian pula sebaliknya.

Berbeda dengan hasil penelitian Nur Mazkiyani and Sigit Handoyo (2017) yang menyatakan bahwa umur perusahaan tidak berpengaruh terhadap audit report lag, Semakin besar atau lebih kecil rasio solvabilitasnya tidak mempengaruhi keterlambatan laporan audit perusahaan. Dan pada hasil penelitian Manda Novy Aristika, Rina Trisnawati dan Cahyaning Dewi Handayani (2012) juga menyatakan bahwa umur perusahaan tidak berpengaruh signifikan terhadap audit report lag.

\section{Pengaruh Ukuran Perusahaan Terhadap Audit Report Lag}

Hasil uji hipotesis pada variable Ukuran Perusahaan memperlihatkan bahwa Ukuran Perusahaan tidak berpengaruh terhadap Audit Report Lag pada perusahaan manufaktur. Dengan demikian, hasil penelitian ini menolak hipotesis yang kedua (H2) yang menyatakan bahwa ukuran perusahaan berpengaruh negatif terhadap audit report lag. Hal ini membuktikan bahwa perusahaan yang besar cendrung memiliki internal kontrol yang baik sehingga mendorong auditornya untuk menyelesaikan proses audit secara tepat waktu.

Hasil penelitian ini sejalan dengan hasil penelitian Fajriyah Indah Septyani (2016) yang menyatakan bahwa ukuran perusahaan tidak memiliki pengaruh terhadap audit report lag. Karena sebagian besar perusahaan yang telah go public tergolong sebagai perusahaan berukuran 
besar karena memiliki aset lebih dari seratus milyar. Perusahaan besar pada umumnya mendapatkan pengawasan dari pihak investor, pemerintah, dan berbagai pihak lainnya, sehingga mereka dituntut agar dapat segera menyelesaikan audit laporan keuangannya. Kemudian hasil penelitian Raras Puspita Asih (2017) juga menunjukkan bahwa ukuran perusahaan tidak berpengaruh terhadap audit report lag.

Berbeda dengan hasil penelitian Bahman Banimahd, Mehdi Moradzadehfard, Mehdi Zeynali (2012) yang menyatakan bahwa ukuran perusahaan berpengaruh terhadap audit report lag, dengan memiliki hubungan positif dengan kelambatan laporan audit pada perusahaan yang terdaftar di TSE. Sejalan dengan hasil penelitian Indriyani dan Supriyati (2012); Prabowo dan Masono (2013); Togasima dan Christiawan (2014) menunjukkan bahwa ukuran perusahaan berpengaruh terhadap audit report lag. Sedangkan menurut penelitian Megayanti dan Budiartha (2016) menyatakan bahwa ukuran perusahaan berpengaruh negatif terhadap audit report lag. Artinya bahwa semakin besar aset perusahaan maka semakin pendek audit report lag.

\section{Pengaruh Reputasi Auditor Terhadap Audit Report Lag}

Hasil uji hipotesis pada variabel Reputasi Auditor memperlihatkan bahwa Reputasi Auditor tidak berpengaruh terhadap Audit Report Lag pada perusahaan manufaktur. Dengan demikian, hasil penelitian ini menolak hipotesis ketiga (H3) yang menyatakan bahwa variabel reputasi auditor berpengaruh negatif terhadap audit report lag. Hal ini berarti bahwa baik perusahaan tersebut melakukan reputasi auditor maupun tidak melakukan reputasi auditor tidak akan mempengaruhi lamanya proses audit laporan keuangan.

Hasil penelitian ini sejalan dengan hasil penelitian yang dilakukan Muhamad Rifqi Abdillah, Agus widodo Mardijuwono and Habiburrochman (2019) yang menyatakan reputasi auditor tidak berpengaruh terhadap audit report lag. Oleh karena itu, penelitian ini menunjukkan bahwa perusahaan yang diaudit oleh KAP Big Four tidak menghasilkan keterlambatan laporan audit yang lebih cepat dari pada perusahaan yang diaudit oleh KAP Non-Big Four. Sejalan juga dengan hasil penelitian Widhiasari dan Budhiarta (2016) yang mengatakan bahwa reputasi auditor tidak berpengaruh terhadap audit report lag.

Berbeda dengan penelitian yang dilakukan oleh Prameswari dan Yusrianthe (2015) yang menyatakan bahwa reputasi KAP mempunyai pengaruh terhadap audit report lag. Sejalan dengan hasil penelitian Ni Nyoman Trisna Dewi Ariyani dan I Ketut Budiartha (2014) menunjukkan bahwa reputasi auditor berpengaruh positif terhadap audit report lag. Kemudian penelitian yang dilakukan oleh penelitian Rusmin dan Evans (2017) menemukan bahwa reputasi auditor berpengaruh negatif dan signifikan terhadap Audit Report Lag.

\section{Pengaruh Pergantian Auditor Terhadap Audit Report Lag}

Hasil uji hipotesis pada variabel Pergantian Auditor memperlihatkan bahwa Pergantian Auditor tidak berpengaruh terhadap Audit Report Lag pada perusahaan manufaktur. Dengan demikian, hasil penelitian ini menolak hipotesis keempat (H4) yang menyatakan bahwa pergantian auditor berpengaruh negatif terhadap audit report lag. Hal ini menunjukkan bahwa walaupun perusahaan melakukan pergantian auditor tidak akan mempengaruhi lamanya waktu penyelesaian audit, Auditor yang baru melakukan perenecanaan audit terlebih dahulu sebelum melakukan proses audit.

Hasil penelitian ini sejalan dengan Apitaningrum (2017) menunjukkan bahwa pergantian auditor tidak berpengaruh signifikan dengan arah positif terhadap Audit Report Lag. Hal ini dikarenakan pergantian auditor dalam suatu perusahaan dapat dilakukan jauh sebelum tanggal 
berakhirnya tahun fiskal, sehingga tidak akan mempengaruhi lamanya proses penyelesaian audit. Sejalan juga dengan penelitian Pinta Uli Tambunan (2014) juga menunjukkan bahwa pergantian auditor tidak berpengaruh terhadap audit report lag. Kemudian hasil pada penelitian Putu Megayanti dan I Ketut Budiartha juga menyatakan bahwa pergantian auditor tidak berpengaruh terhadap audit report lag pada perusahaan yang terdaftar di Bursa Efek Indonesia tahun 2013 dan 2014.

Berbeda dengan penelitian Rustriarini dan Mitra (2013) membuktikan bahwa pergantian auditor berpengaruh positif terhadap audit report lag. Hal ini dikarenakan perusahaan belum dapat memilih auditor pengganti yang berkompeten dibidangnya sesuai dengan kebutuhan perusahaan sehingga proses penyelesaian audit atas laporan keuangan belum bisa dilaksanakan dengan tepat waktu.

\section{KESIMPULAN, DAN SARAN \\ Kesimpulan}

Setelah dilakukan analisis data dengan menggunakan analisis regresi linear berganda maka dapat disimpulkan sebagai berikut :

1. Umur Perusahaan berpengaruh terhadap Audit Report Lag pada perusahaan manufaktur yang terdaftar di BEI tahun 2014-2018.

2. Ukuran Perusahaan tidak berpengaruh terhadap Audit Report Lag pada perusahaan manufaktur yang terdaftar di BEI tahun 2014-2018.

3. Reputasi Auditor tidak berpengaruh terhadap Audit Report Lag pada perusahaan manufaktur yang terdaftar di BEI tahun 2014-2018.

4. Pergantian Auditor tidak berpengaruh terhadap ketepatan Audit Report Lag pada perusahaan manufaktur yang terdaftar di BEI tahun 2014-2018.

\section{Saran}

Adapun saran-saran yang bisa disampaikan sehingga untuk penelitian selanjutnya bisa mendapatkan hasil yang jauh lebih baik, antara lain :

1. Bagi Perusahaan

Diharapkan agar perusahaan memperhatikan factor-factor yang mempengaruhi Audit report lag, seperti umur perusahaan yang berpengaruh terhadap audit report lag tersebut, umur perusahaan ini dihitung dari tanggal perusahaan itu berdiri sampai dengan saat perusahaan melakukan tutup buku. Semakin lama umur suatu perusahaan, maka semakin pendek audit report lag perusahaan tersebut, ini dikarenakan perusahaan yang telah lama berdiri dinilai lebih mampu dan telah berpengalaman dalam mengumpulkan, memproses, dan menghasilkan informasi yang dibutuhkan dalam proses audit. Hal ini akan menimbulkan banyaknya pemeriksaan yang harus dilakukan oleh auditor terkait dengan tingkat kompleksitas yang tinggi, sehingga akan menimbulkan lamanya proses audit yang dilakukan oleh auditor tersebut. Dan pada akhirnya akan berakibat pada keterlambatan penyampaian laporan keuangan tahunannya.

2. Bagi Penelitian Selanjutnya

a. Penelitian selanjutnya diharapkan agar dapat menambah beberapa variabel independen lainnya yang mungkin memiliki pengaruh terhadap audit report lag seperti laverage, solvabilitas, profitabilitas, umur perusahaan dan menambah periode pengamatan agar mendapat hasil yang lebih baik. 
b.Penelitian selanjutnya agar tidak terfokus pada satu sector perusahaan sebagai objek penelitian, tetapi masih banyak sector perusahaan lainnya seperti perusahaan pertambangan, perbankan, BUMN, dan lain-lain.

\section{DAFTAR PUSTAKA}

Abdillah, M. R., Mardijuwono, A. W., \& Habiburrochman, H. (2019). The effect of company characteristics and auditor characteristics to audit report lag. Asian Journal of Accounting Research, 129-144.

Abdillah, Muhammad Rifqi, Agus Widodo Mardijuwono \& Habiburrochman. (2019). The Effect of Company Characteristic and Auditor Characteristic to Audit Report Lag. Asian Journal of Accounting Research. 4(1), 129-144.

Amariyah, Siti, Masyhad dan Nurul Qomari, 2017. "Pengaruh Profitabilitas, Solvabilitas dan Umur Perusahaan Terhadap Audit Report Lag pada Perusahaan Manufaktur Yang Terdaftar Dibursa Efek Indonesia Periode 2013-2015”, Jurnal Ekonomi Akuntansi, 3(3).

Anastasia Petronila, Thio.2007. Analisis Skala Perusahaan, Opini Audit, dan Umur Perusahaan atas Audit Delay. Akuntabilitas. Vol. 6, No. 2. Maret 2007, hal. 129- 141. Fakultas Ekonomi Unika Atma Jaya. Jakarta.

Anggraeni dan Kiswaran. 2011. Pengaruh Pemanfaatan Fasilitas Perpajakan Sunset Policy Terhadap Tingkat Kepatuhan Wajib Pajak. Semarang. Skripsi. Universitas Diponegoro.

Apitaningrum, Aprilia. 2017. "Pengaruh pergantian auditor, opini audit, ukuran perusahaan, dan laba rugi terhadap audit report lag". Skripsi Tahun 2017.

Arens, Alvin, et al. 2011. Auditing dan Jasa Assurance Pendekatan Terpadu Jilid 1. Jakarta: Penerbit Salemba Empat.

Aristika, Manda Novy, Rina Trisnawati dan Cahyaning Dewi Handayani.2015. Pengaruh Opini Audit, ukuran perusahaan, umur perusahaan dan laba rugi perusahaan terhadap audit report lag. Menakar Peran Profesi sebagai Engine of Reform dalam Pembangunan Global Berkelanjutan.

Ariyani, Ni Nyoman Trisna Dewi dan I Ketut Budiartha. 2014. Pengaruh Profitabilitas, Ukuran Perusahaan, Kompleksitas Operasi Perusahaan Dan Reputasi Kap Terhadap Audit Report Lag Pada Perusahaan Manufaktur. E-Jurnal Akuntansi Universitas Udayana ISSN: 2302-8556. Volume 8. Nomor 2.

Asih, Raras Puspita. 2017. Pengaruh Opini Audit, Ukuran KAP, Auditor Switching, Profitabilitas, Ukuran Perushaan Terhadap Audit Report Lag Pada Perusahaa Manufaktur yang Terdaftar Di BEI Tahun 2011- 2015. Jurnal. STIE Perbanas Surabaya.

Banimahd, et al., 2012. Audit Report Lag and Auditor Change: Evidence from Iran. Journal of Basic and Applied Scientific Research, 2(12).

Bangun, P., dkk. Faktor-Faktor yang Mempengaruhi Audit Report Lag Pada Perusahaan yang Listed di Bursa Efek Indonesia. Proceeding Pekan Ilmiah Dosen. FEB-UKSW. Salatiga. 14 Desember 2012.

Basuki, Sulistyo. 2010. Metode Penelitian. Jakarta : Penaku.

Bursa Efek Indonesia. Jurnal Bisnis dan Akuntansi Vol. 12, No. 3, Halaman 175186.Universitas Tarumanegara. 
Christian Noverta Togasima dan Yulius Jogi Christiawan, 2014) Analisis Faktor-faktor Yang Mempengaruhi Audit Report Lag Pada Perusahaan Yang Terdaftar di Bursa Efek Indonesia Pada Tahun 2012. Business Accounting Review, Vol. 2. No. 2, Juli 2012: 151-159.

Dewangga, Arga dan Herry Laksito. 2015. Faktor-faktor Yang Berpengaruh Terhadap Audit Report Lag. Diponegoro Journal Of Accounting. 4 (3).

Dibia, N.O. dan J.C. Onwuchekwa. (2013). An Examination of The Audit Report Lag of Companies Quoted in The Nigeria Stock Exchange. International Journal of Business and Social Research (IJBSR), 3 (9), hal. 8-16.

Fodio, M. I., Oba, V. C., Oiukoju, A. B., \& Zik-rullahi, A. A. (2015). IFRS Adoption, Firmm Traits and Audit Timeliness: Evidence from Nigeria. ACTAUNIVERSITAS DANUBIUS Vol. 11, No. 3, 106-119.

Ikatan Akuntan Indonesia (IAI). 2016. Standar Akuntansi Keuangan revisi 2016. Salemba Empat. Jakarta

Indra, Novelia Sagita dan Dicky Arisudhana. 2012. "Faktor-Faktor Yang Mempengaruhi Audit Delay Pada Perusahaan Go Public di Indonesia". JP Akuntansi dd Vol. 1 No. 2.

Indriyani, Rosmawati Endang dan Supriyati. 2012. Faktor-Faktor yang Mempengaruhi Audit Report Lag Perusahaan Manufaktur Di Indonesia Dan Malaysia. The Indonesian Accounting Review. Vol. 2 No. 2 Hlm. 185-202.

Iskandar, Meylisa Januar dan Estralita Trisnawati. 2010. Faktor-Faktor yang Mempengaruhi Audit Report Lag Pada Perusahaan Yang Terdaftar di Bursa Efek Indonesia. Jurnal Bisnis dan Akuntansi Vol. 12, No. 3, Halaman 175-186. UniversitasTarumanegara

Juanita dan Satwiko. 2012. Pengaruh Ukuran Kantor Akuntan Publik, Kepemilikan, I Laba Rugi, Profitabilitas dan Solvabilitas terhadap Audit Report Lag. Jurnal Bisnis dan Akuntansi, vol 14, no. 1, hlm. 31-40

Laksono, Firman Dwi dan Mu'id Dul, 2014. "Analisis Faktor-faktor Yang Mempengaruhi Audit delay dan Ketetapan Waktu Publikasi Laporan Keuangan" (Diponegoro Journal of Accounting Volume 3, Nomor 1, Tahun 2014).

Lunenburg. 2012. Compliance Theory and Organizational Efektiveness. International Journal Of Scholarly Academic Intellectual Diversity Vol. 14, No.1

Lianto dan Kusuma. 2010. "Faktor -Faktor yang Berpengaruh Terhadap Audit Report Lag". Jurnal Bisnis dan Akuntansi.Vol. 12, No.2

Mazkiyani, Handoyo. Audit Report Lag of Listed Companies inIndonesia Stock Exchange.Jurnal Aplikasi Bisnis.Vol.17. No.1. Juli 2017

Megayanti dan Budiartha. 2016. "Pengaruh Pergantian Auditor, Ukuran Perusahaan, Laba Rugi Dan Jenis Perusahaan Pada Audit Report Lag”. E-Jurnal AkuntansiUniversitas Udayana.

Niputu Dewiyani Swami dan Made Yeni Latrini, 2013.” Pengaruh Corporate Governance

Terhadap Audit Report Lag", Jurnal Akuntansi Universitas Udayana Prasongkoputra, Adi Nugraha, 2013. "Faktor-faktor yang mempengaruhi Audit Delay". Skripsi. Departemen Akuntansi, UIN Syarif hidayatullah, Jakarta., $\quad$ Volume 4.3 hal 530-549.

Otoritas Jasa Keuangan, 2016, Peraturan Otoritas Jasa Keuangan Nomor 29/POJK.04/2016 tentang Laporan Tahunan Emiten atau Perusahaan Publik, Jakarta: Otoritas Jasa Keuangan Republik Indonesia 
Pawitri dan Yadnyana. 2015. Pengaruh Audit Delay, Opini Audit, Reputasi Auditor Dan Pergantian Manajemen pada Voluntary Auditor Switching. E-jurnal Akuntansi Universitas Udayana. 10 (1). 214-228

Prabowo, Pebi Putra Tri dan Marsono. 2013. "Faktor-Faktor Yang Mempengaruhi Audit Delay (Studi Empiris Pada Perusahaan Manufaktur yang Terdaftar di Bursa Efek Indonesia Tahun 2013-2015)”, Skripsi Fakultas Ekonomi dan Bisnis Universitas Muhamadiyah Surakarta

Prahartari, Frida Aurora, (2013). "Faktor-faktor yang Mempengaruhi Auditor Switching". Skripsi, Universitas Islam Negeri Syarif Hidayatullah : Jakarta.

Prameswari dan Yustrianthe. 2015. "Analisis Faktor - Faktor Yang Memengaruhi Audit Delay (Studi Empiris Pada Perusahaan Manufaktur Yang Terdaftar Di Bursa Efek Indonesia)". Jurnal Akuntansi/ Volume XIX, Nomer 01, Sekolah Tinggi Ilmu Ekonomi YAI Jakarta.

Rizqillah, Ulin Nuraini, (2013). "Pengaruh Opini Audit, Pergantian Manajemen, dan Reputasi Auditor terhadap Pergantian Auditor". Jurnal Publikasi Universitas Muhammadiyah : Surakarta.

Rusmin, Rusmin dan John Evans. (2017). "Audit Quality and Audit Report Lag: Case of Indonesian Listed Companies". Asian Review of Accounting, Vol. 25 Issue: 2, pp. 191-210

Rustiarini dan Sugiarti. 2013."Pengaruh Karakteristik Auditor, Opini Audit, Audit Tenure, Pergantian Auditor Pada Audit Delay”.Jurnal Ilmiahdan Humanika, volume 2, nomor 2, Singaraja.

Sekaran, Uma., dan Roger Bougie 2013.Research Methods For Business Edisi 4.Buku 2, Jakarta: Wiley

Septyani, Fajriyah Indah. Pengaruh Profitabilitas, Solvabilitas, Ukuran Perusahaan, Opini Audit Dan Ukuran Kap Terhadap Audit Report Lag. Skripsi. Sekolah Tinggi Imu Ekonomi Perbanas Surabaya.

Suwardjono. 2002. Akuntansi Pengantar : Proses Penciptaan Data Pendekatan Sistem, Yogyakarta : BPFE.

Tambunan, Pinta Uli. 2014. Pengaruh Opini Audit, Pergantian Auditor Dan Ukuran Kantor Akuntan Publik Terhadap Audit Report Lag. E-Jurnal Akuntansi Universitas Negeri Padang. Vol. 3, No. 1.

Widhiasari, Ni Made Shinta dan Budiartha, I Ketut. 2016. Pengaruh Umur Perusahaan, Ukuran Perusahaan, Reputasi Auditor, dan Pergantian Auditor Terhadap Audit Report Lag. E-Jurnal Akuntansi Universitas Udayana ISSN: 2302-8556. Volume 15. Nomor 1. www.idx.co.id 